Check for updates

Cite this: RSC Adv., 2018, 8, 26906

\title{
Exploration of the modification of carbon-based substrate surfaces in aqueous rechargeable zinc ion batteries $\uparrow$
}

\author{
Jing Xin, Chang Liu, Ziwen Qiu, Jingjing Zhou, Qian Wang, Yang Liu (DD * \\ and Bingkun Guo*
}

Received 31st May 2018

Accepted 16th July 2018

DOI: $10.1039 / \mathrm{c} 8 \mathrm{ra0} 4643 \mathrm{c}$

The hydrophobic surfaces of carbon-based substrates lead to a huge interface impedance in aqueous rechargeable zinc ion batteries (ZIBs). Herein, we try to regulate the morphology and investigate the effects of polar groups on the substrate surface. With the treated substrate, the cyclic and rate performances of $\mathrm{MnO}_{2}$ electrodes are improved by $\sim 42.5 \%$ and $97 \mathrm{~mA} \mathrm{~h} \mathrm{~g}$.

\section{Introduction}

As an important type of energy storage device, zinc aqueous batteries have been the focus of investigations. Many cathodes such as $\mathrm{Na}_{0.95} \mathrm{MnO}_{2},{ }^{1} \mathrm{NiO},{ }^{2}$ and $\mathrm{Co}_{3} \mathrm{O}_{4}$ (ref. 3 and 4 ) have been introduced into battery systems, among which $\mathrm{MnO}_{2}$ has presented really high application value. The $\mathrm{Zn}-\mathrm{MnO}_{2}$ battery has obtained a huge market share of energy storage equipment since being invented in $18600^{5,6}$ However, the hydroxyl ion would passivate the zinc anode and this results in the rapid fading of capacity with cycling, which limits the further applications of traditional ZIBs based on alkaline electrolytes. ${ }^{7-10}$ Thus neutral aqueous electrolytes have been introduced to aqueous ZIBs to meet the demand for rechargeable energy storage devices which are safe, with good reversibilities, ideal capacities, fast charge-discharge capabilities, low costs and environmental friendliness. ${ }^{11,12}$ In 2012, F. Y. Kang et al. proposed a rechargeable $\mathrm{Zn}-\mathrm{MnO}_{2}$ battery with $1.3 \mathrm{~V}$ open circuit voltage and $210 \mathrm{~mA} \mathrm{~h} \mathrm{~g}^{-1}$ in a mild aqueous electrolyte. ${ }^{13}$ Afterwards, many neutral or mildly acidic aqueous electrolytes involving simple or mixed cations such as $\mathrm{Zn}^{2+}, \mathrm{Mn}^{2+}$, or $\mathrm{Li}^{+}$and anions e.g. $\mathrm{SO}_{4}{ }^{2-}, \mathrm{NO}_{3}{ }^{-}, \mathrm{Cl}^{-}$, or $\mathrm{TFSI}^{-}$have been introduced into $\mathrm{Zn}$ ion secondary energy storage systems. ${ }^{13-16} \mathrm{In} \mathrm{J}$. Chen's work, the ZIB in an aqueous electrolyte involving $3 \mathrm{M} \mathrm{Zn}\left(\mathrm{CF}_{3}\right.$ $\left.\mathrm{SO}_{3}\right)_{2}$ and $0.1 \mathrm{M} \mathrm{Mn}\left(\mathrm{CF}_{3} \mathrm{SO}_{3}\right)_{2}$ shows a capacity of $307 \mathrm{~mA} \mathrm{~h} \mathrm{~g}^{-1}$ which approaches the theoretical capacity of $\mathrm{MnO}_{2}$ $\left(308 \mathrm{~mA} \mathrm{~h} \mathrm{~g}^{-1}\right)$, and has a $94 \%$ reversible capacity retention over 2000 cycles. $^{17}$

The simulation of C. J. Xu et al. indicates the insertion of $\mathrm{Zn}^{2+}$ into transition metal oxides such as $\mathrm{MnO}_{2}$ is thermodynamically easier and more stable than that of monovalent alkali

Materials Genome Institute, Shanghai University, Shanghai, 200444, China. E-mail: liuyang81@shu.edu.cn; guobingkun@shu.edu.cn

$\dagger$ Electronic supplementary information (ESI) available. See DOI: $10.1039 / \mathrm{c} 8 \mathrm{ra} 04643 \mathrm{c}$ ions, meaning there is potential for ZIBs with fast chargedischarge. ${ }^{18}$ To improve the performance of ZIBs, various cathode materials and compounds have been investigated. In the published studies, the impacts of the $\mathrm{MnO}_{2}$ crystal form, size and cathode additives in ZIBs have been discussed. ${ }^{19-22} \mathrm{~F}$. Y. Cheng et al. designed a zinc manganese oxide/carbon hybrid cathode which exhibits a reversible capacity of $150 \mathrm{~mA} \mathrm{~h} \mathrm{~g}^{-1}$ at $500 \mathrm{~mA} \mathrm{~g}^{-1}$ in $3 \mathrm{M} \mathrm{Zn}\left(\mathrm{CF}_{3} \mathrm{SO}_{3}\right)_{2}$ aqueous solution. ${ }^{23}$ However, the current results are still unsatisfactory. In a typical ZIB, the electrode particles are loaded on a substrate, which is also the current collector. ${ }^{24}$ The common substrates for ZIBs are carbonbased materials, such as carbon paper (CP). A typical CP surface consists of various aromatic rings and other hydrophobic groups, which present incompatibility with aqueous electrolytes and lead to the large interface impedance..$^{25}$ To remedy the drawbacks, some organic additives have been introduced into ZIBs, and both the environmental risk and prime cost have been improved. ${ }^{26-29}$

Some reports suggest the introduced oxygen-containing groups would significantly improve the electric conductivity and hydrophilic properties of carbon materials. ${ }^{30,31}$ Therefore, this work will focus on the surface modification of CP. The oxygen-containing groups could be introduced to the CP surfaces though a simple route by soaking in hybrid acids at different temperatures, then the hydrophobicity of the CPs would be regulated and affect the charge-discharge behaviors of the $\mathrm{MnO}_{2} / \mathrm{CP}$ cathode.

\section{Results and discussion}

The original and treated carbon-based materials are marked as $\mathrm{O}-\mathrm{CP}$ and a-CP respectively, and sample surfaces are examined using SEM first. As shown in Fig. 1a, there are many folds on the surface of the original carbon fiber. After the treatment in hybrid acid at $30{ }^{\circ} \mathrm{C}$, the sample shows a surface with some bulges on the carbon fibers without a strong indication of the 

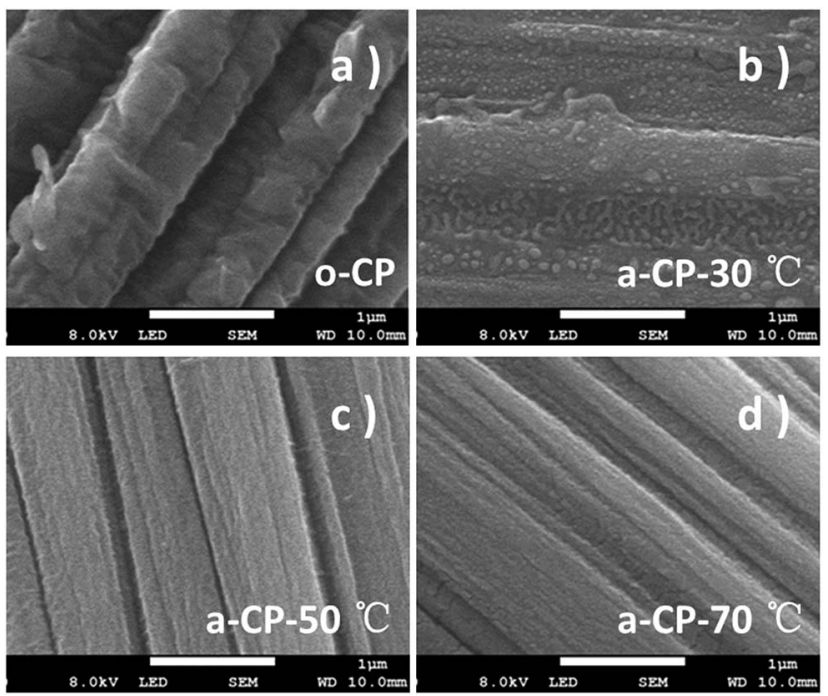

Fig. 1 SEM images of o-CP (a) and CPs with acid treated at 30, 50, and $70{ }^{\circ} \mathrm{C}(\mathrm{b}-\mathrm{d})$.

fold (Fig. 1b). When the temperature is increased, the surfaces of the a-CPs are smoother and clearer. The rods can be connected together and form a plane (Fig. 1c). With the treatments of 50 and $70^{\circ} \mathrm{C}$, no obvious folds or attachments are detected on the surface of the CP, and fibers are adhered (Fig. 1c and d).

FTIR and XPS were utilized to analyze the variations of groups on the CPs. No clear sign of the absorption peak belonging to any organic group is detected on o-CP. After the acid treatment, large new peaks appeared at 1574, 1442, 1227, 1165 and $1028 \mathrm{~cm}^{-1}$, which could be assigned to $\mathrm{C}=\mathrm{O}, \mathrm{N}-\mathrm{O}$, $\mathrm{Ph}-\mathrm{O}, \mathrm{C}-\mathrm{O}$ and $\mathrm{O}-\mathrm{H}$ stretching. ${ }^{32,33}$ With the increase in the acidification temperature, the infrared intensities of the oxygencontaining functional groups are strengthened. The former indicates the introduction of oxygen-containing groups such as carbonyl, carboxyl and hydroxyl groups during the acidification of CPs in concentrated nitric and sulfuric acids, and the latter should be attributed to the enhanced reaction kinetics. XPS spectra show similar evidence. As shown in Fig. 2b, the intensities of peaks due to $\mathrm{O} 1 \mathrm{~s}$ in a-CPs are stronger and wider than in o-CPs, suggesting there are more oxygen-containing groups on the surfaces of the a-CPs, and an elevated temperature is conducive to the formation of chemical bonds, and this is consistent with the results of FTIR. ${ }^{34-37}$ With the increase in
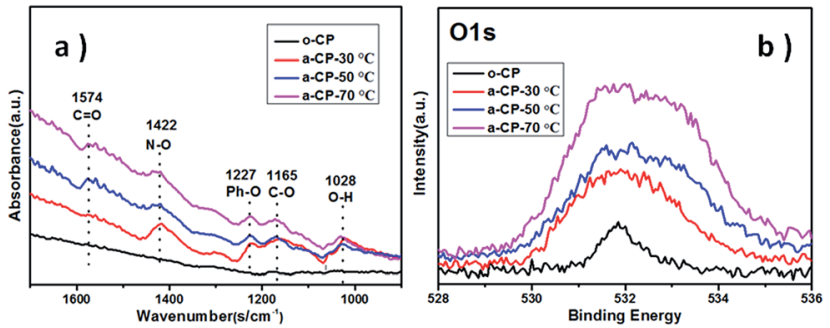

Fig. 2 FTIR (a) and XPS (b) spectra of the original and acid-treated CPs. processing temperature, the intensity of the peak due to a-CP$70{ }^{\circ} \mathrm{C}$ is the strongest and widest (Fig. 2b).

With the increase in oxygen-containing functional groups on the surfaces of a-CPs, the compatibility of a-CPs and water should be regulated. The compatibility of original and acidtreated CPs with deionized water is measured using a contact angle meter. As shown in Fig. 3, the contact angle of o-CP is $138.74^{\circ}$, and those of the acid-treated CPs are 130.58, 122.51 and $116.53^{\circ}$, corresponding to the processing temperatures of 30,50 and $70{ }^{\circ} \mathrm{C}$. At the temperature of $70{ }^{\circ} \mathrm{C}$, the acidified $\mathrm{CP}$ presents the best wettability with deionized water, which should be attributed to the number of oxygen-containing groups as shown in the FTIR and XPS spectra.

The $\mathrm{MnO}_{2} / \mathrm{CP}$ cathodes were prepared by pushing a slurry of $\beta-\mathrm{MnO}_{2}$, acetylene black and PVDF into different CPs and drying under vacuum. Fig. 4a shows cyclic voltammetry (CV) curves of $\mathrm{Zn}-\mathrm{MnO}_{2}$ batteries with different cathodes. The curves show one oxidation peak at $\sim 1.56 \mathrm{~V} v s . \mathrm{Zn}^{2+} / \mathrm{Zn}$ and two reduction peaks at 1.28 and $1.37 \mathrm{~V} v s . \mathrm{Zn}^{2+} / \mathrm{Zn}$, corresponding to the insertion/extraction of $\mathrm{Zn}^{2+}$ into/from the tunnel of $\beta-\mathrm{MnO}_{2}$ (Fig. S1 $\dagger$ ). ${ }^{32}$ The shapes and peak positions of the curves are similar, which suggests the introduced oxygen-containing groups on CPs do not affect the redox reactions in $\mathrm{MnO}_{2}$. As shown in Fig. 4b, the similar intercept impedances of the samples suggest the solution resistance is the same in the cells using the same electrolyte. The depressed semicircle in the medium frequency region should be related to the charge transfer resistance at the electrode/electrolyte interface, and Fig. $4 \mathrm{~b}$ shows this resistance of o-CP is much larger than that of a-CPs. Combined with the contact angles, the significant difference in resistances should be attributed to ion diffusion, which is affected by the compatibility of the substrate and the aqueous solution.

The electrochemical performances of the $\mathrm{MnO}_{2} / \mathrm{o}-\mathrm{CP}$ and $\mathrm{MnO}_{2}$ /a-CP electrodes at various current densities were investigated in Fig. 4c and d. Fig. 4c shows the cycling performances of the cells at $308 \mathrm{~mA} \mathrm{~g}^{-1}$ between 1.0 and $1.8 \mathrm{~V}$ vs. $\mathrm{Zn}^{2+} / \mathrm{Zn}$. After a few conditioning cycles, the $\mathrm{MnO}_{2} / \mathrm{o}-\mathrm{CP}$ cathode shows

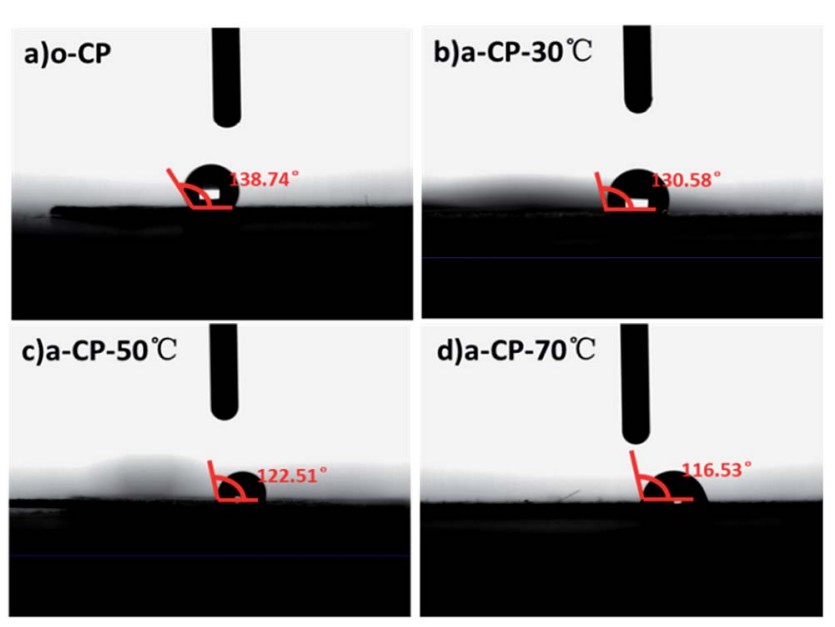

Fig. 3 The contact angles of different CPs. 

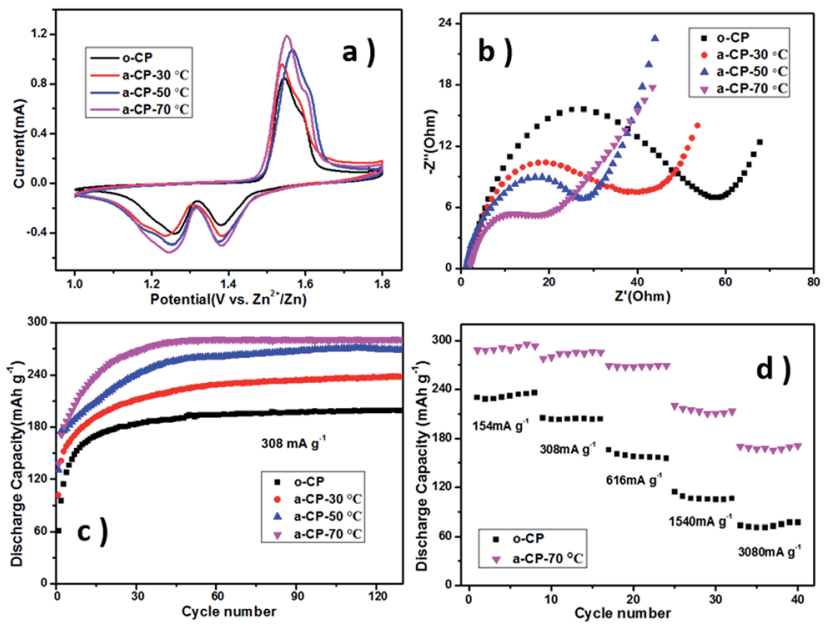

Fig. $4 \mathrm{CV}$ curves of the $\mathrm{MnO}_{2} / \mathrm{CP}$ electrode in $2 \mathrm{M} \mathrm{ZnSO}_{4}$ and $0.2 \mathrm{M}$ $\mathrm{MnSO}_{4}$ hybrid aqueous electrolytes at a sweep rate of $0.5 \mathrm{mV} \mathrm{s}{ }^{-1}$ (a), electrochemical impedance spectroscopy (EIS) after the CV test (b), and cyclic and rate performances of the cells utilizing different substrates (c and d).

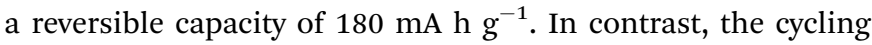
performances of the $\mathrm{MnO}_{2} / \mathrm{a}-\mathrm{CP}$ electrodes are significantly improved. The capacities of the cells are 220 and $260 \mathrm{~mA} \mathrm{~h} \mathrm{~g}^{-1}$ when the acidification temperatures of the CPs are 30 and $50^{\circ} \mathrm{C}$ respectively. At the acidification temperature of $70{ }^{\circ} \mathrm{C}$, the reversible capacity of $\mathrm{MnO}_{2} / \mathrm{a}-\mathrm{CP}$ reaches $285 \mathrm{~mA} \mathrm{~h} \mathrm{~g}{ }^{-1}$ and it has a $98.2 \%$ capacity retention at the 130 th cycle, $\sim 42.5 \%$ higher than $\mathrm{MnO}_{2} / \mathrm{o}-\mathrm{CP}$.

Rate performances are shown in Fig. $4 \mathrm{~d}$ and $\mathrm{S} 3 . \dagger$ The cell with a-CP- $70{ }^{\circ} \mathrm{C}$ also presents much better performances than the original one at different current densities. Even at a high rate up to $3080 \mathrm{~mA} \mathrm{~g}^{-1}, \mathrm{MnO}_{2} / \mathrm{a}-\mathrm{CP}-70{ }^{\circ} \mathrm{C}$ still delivers a reversible capacity of $170.2 \mathrm{~mA} \mathrm{~h} \mathrm{~g}^{-1}, \sim 97 \mathrm{~mA} \mathrm{~h} \mathrm{~g}^{-1}$ higher than the sample utilizing o-CP. With the increasing treatment temperature, the polarization of $\mathrm{MnO}_{2} / \mathrm{a}-\mathrm{CP}$ cathodes in chargedischarge processes is reduced (Fig. S2 and S3†), and the cyclic and rate performances of the cells using a-CPs as substrates improve, presenting a similar trend as the hydrophilicities of samples determined by the quantities of oxygen-containing groups, resulting from the rising treatment temperature.

\section{Conclusions}

The modification of carbon-based substrate surfaces in aqueous rechargeable ZIBs was investigated. The oxygen-containing group-rich CP surfaces were formed by being treated in hybrid acids at different temperatures, presenting good hydrophilic properties. With the increased treatment temperature, the cells using the a-CPs present improved electrochemical performances, which should be attributed to the enhanced number of hydrophilic groups on carbon substrates in ZIBs. The reversible capacity of the $\mathrm{MnO}_{2} / \mathrm{a}-\mathrm{CP}-70{ }^{\circ} \mathrm{C}$ sample was stabilized at $285 \mathrm{~mA} \mathrm{~h} \mathrm{~g}^{-1}$ in 130 cycles at a current of $308 \mathrm{~mA} \mathrm{~g}^{-1}, \sim 42.5 \%$ higher than that of the cathode using o-CP. The capacity of $\mathrm{MnO}_{2} / \mathrm{a}-\mathrm{CP}-70{ }^{\circ} \mathrm{C}$ also remains at $170.2 \mathrm{~mA} \mathrm{~h} \mathrm{~g}{ }^{-1}$ even at a high current of $3080 \mathrm{~mA} \mathrm{~g}^{-1}, \sim 97 \mathrm{~mA} \mathrm{~h} \mathrm{~g}^{-1}$ higher than that of $\mathrm{MnO}_{2} / \mathrm{o}-\mathrm{CP}$. Our results reveal that the surface modification of CPs by acidification-thermal treatment is a promising approach to improve the electrochemical performances of aqueous ZIBs.

\section{Conflicts of interest}

There are no conflicts to declare.

\section{Acknowledgements}

This work was supported by the National Natural Science Foundation of China (Grant No. 21503247, 51602190), the Program for Professor of Special Appointment (Eastern Scholar) at Shanghai Institutions of Higher Learning, and the 111 Project (D16002).

\section{References}

1 B. H. Zhang, Y. Liu, X. W. Wu, Y. Q. Yang, Z. Chang, Z. B. Wen and Y. P. Wu, Chem. Commun., 2014, 50, 12091211.

2 Y. X. Zeng, Y. Meng, Z. Z. Lai, X. Y. Zhang, M. H. Yu, P. P. Fang, M. M. Wu, Y. X. Tong and X. H. Lu, Adv. Mater., 2017, 29, 1702698.

3 X. W. Wang, F. X. Wang, L. Y. Wang, M. X. Li, Y. F. Wang, B. W. Chen, Y. S. Zhu, L. F. Fu, L. S. Zha, L. X. Zhang, Y. P. Wu and W. Huang, Adv. Mater., 2016, 28, 4904-4911.

4 P. Tan, B. Chen, H. R. Xu, W. Z. Cai, W. He, M. L. Liu, Z. P. Shao and M. Ni, Small, 2018, 1800225.

5 D. Aurbach, Z. Lu, A. Schechter, Y. Gofer, H. Gizbar, R. Turgeman, Y. Cohen, M. Moshkovich and E. Levi, Nature, 2000, 407, 724-727.

6 M. Winter and R. J. Brodd, Chem. Rev., 2004, 104, 4245-4270.

7 Q. Li, R. Cao, J. Cho and G. Wu, Adv. Eng. Mater., 2014, 4, 1301415.

8 K. V. Kordesch, C. Fabjan, J. Daniel-Ivad and J. Oliveira, J. Power Sources, 1997, 65, 77-80.

9 H. Schlörb, M. Bungs and W. Plieth, Electrochim. Acta, 1997, 42, 2619-2625.

10 Y. Mo, Y. Hu, I. T. Bae, B. Miller, M. R. Antonio and D. A. Scherson, J. Electrochem. Soc., 1997, 144, 1598-1603.

11 F. R. McLarnon and E. J. Cairns, J. Electrochem. Soc., 1991, 138, 645-656.

12 Z. Rogulski, M. Chotkowski and A. Czerwiski, J. New Mater. Electrochem. Syst., 2006, 9, 333-338.

13 C. Xu, B. Li, H. Du and F. Kang, Angew. Chem., Int. Ed., 2011, 51, 933-935.

14 C. Xu, H. Du, B. Li, F. Kang and Y. Zeng, Electrochem. SolidState Lett., 2009, 12, A61-A65.

15 X. Zhu, T. N. L. Doan, Y. Yu, Y. Tian, K. E. K. Sun, H. Zhao and P. Chen, Ionics, 2016, 22, 71-76.

16 C. Xu, H. Du, B. Li, F. Kang and Y. Zeng, J. Electrochem. Soc., 2009, 156, A73-A78.

17 N. Zhang, F. Cheng, J. Liu, L. Wang, X. Long, X. Liu, F. Li and J. Chen, Nat. Commun., 2017, 8, 405. 
18 C. Xu, Y. Chen, S. Shi, J. Li, F. Kang and D. Su, Sci. Rep., 2015, 5, 14120.

19 M. Minakshi, M. Blackford and M. Ionescu, J. Alloys Compd., 2011, 509, 5974-5980.

20 Q. Feng, K. Yanagisawa and N. Yamasaki, J. Porous Mater., 1998, 5, 153-162.

21 B. Hertzberg, L. Sviridov, E. A. Stach, T. Gupta and D. Steingart, J. Electrochem. Soc., 2014, 161, A835-A840.

22 O. Ghodbane, J.-L. Pascal and F. Favier, ACS Appl. Mater. Interfaces, 2009, 1, 1130-1139.

23 N. Zhang, F. Cheng, Y. Liu, Q. Zhao, K. Lei, C. Chen, X. Liu and J. Chen, J. Am. Chem. Soc., 2016, 138, 12894-12901.

24 J. Lee, J. B. Ju, W. I. Cho, B. W. Cho and S. H. Oh, Electrochim. Acta, 2013, 112, 138-143.

25 W. Dai, H. Wang, X.-Z. Yuan, J. J. Martin, D. Yang, J. Qiao and J. Ma, Int. J. Hydrogen Energy, 2009, 34, 9461-9478.

26 S.-L. Chou, J.-Z. Wang, S.-Y. Chew, H.-K. Liu and S.-X. Dou, Electrochem. Commun., 2008, 10, 1724-1727.

27 S. W. Lee, J. Kim, S. Chen, P. T. Hammond and Y. ShaoHorn, ACS Nano, 2010, 4, 3889-3896.

28 J.-S. Ye, X. Liu, H. F. Cui, W.-D. Zhang, F.-S. Sheu and T. M. Lim, Electrochem. Commun., 2005, 7, 249-255.
29 Q. Cheng, J. Tang, J. Ma, H. Zhang, N. Shinya and L.-C. Qin, Carbon, 2011, 49, 2917-2925.

30 S. C. Tsang, Y. K. Chen, P. J. F. Harris and M. L. H. Green, Nature, 1994, 372, 159.

31 R. M. Lago, S. C. Tsang, K. L. Lu, Y. K. Chen and M. L. H. Green, J. Chem. Soc., Chem. Commun., 1995, 13551356.

32 F. Avilés, J. V. Cauich-Rodríguez, L. Moo-Tah, A. May-Pat and R. Vargas-Coronado, Carbon, 2009, 47, 2970-2975.

33 H. W. Siesler, Y. Ozaki, S. Kawata and H. M. Heise, NearInfrared Spectroscopy: Principles, Instruments, Applications, 2007.

34 J. Cui, W. Wang, Y. You, C. Liu and P. Wang, Polymer, 2004, 45, 8717-8721.

35 Y. M. Shulga, T.-C. Tien, C.-C. Huang, S.-C. Lo, V. E. Muradyan, N. V. Polyakova, Y.-C. Ling, R. O. Loutfy and A. P. Moravsky, J. Electron Spectrosc. Relat. Phenom., 2007, 160, 22-28.

36 H. Meng, G. X. Sui, P. F. Fang and R. Yang, Polymer, 2008, 49, 610-620.

37 D.-Q. Yang, J.-F. Rochette and E. Sacher, J. Phys. Chem. B, 2005, 109, 7788-7794. 